\title{
Effect of partial substitution of Riceberry rice flour on rice noodles quality
}

\author{
*Thongkaew, C. and Singthong, J. \\ Department of Agro-Industry, Faculty of Agriculture, Ubon Ratchathani University, Ubon Ratchathani, CO \\ 34190 Thailand
}

\begin{abstract}
Article history:
Received: 20 May 2020

Received in revised form: 22

July 2020

Accepted: 17 October 2020

Available Online: 6

December 2020

\section{Keywords:}

Rice noodles,

Riceberry rice,

Physicochemical properties,

Functional properties
\end{abstract}

\section{DOI:}

https://doi.org/10.26656/fr.2017.4(S4).002

\begin{abstract}
Rice is major economic potential plants in the North-East of Thailand, especially in Ubon Ratchathani province. Rice noodle in Ubon Ratchathani have called Ubon noodles is local wisdom of indigenous food as one tambon one product (OTOP). The objective of this research was focused on the development of rice noodles with Riceberry rice flour (RRF) to obtain the higher value product due to Riceberry rice is a good source of vitamins, minerals, and bioactive compounds. The current work investigates the proximate analysis, the physicochemical properties, some bioactive compounds, and the cooking properties of flour. The rice noodle quality was observed by evaluating the textural property, cooking quality, and sensory. The results showed that RRF contained $9.50 \pm 0.13 \%$ protein, $6.38 \pm 0.06 \%$ fat, and $23.33 \pm 0.00 \%$ amylose. The study of bioactivity of RRF revealed that total phenolic, flavonoids and anthocyanin content were $495 \pm 0.00 \mathrm{mg}$ gallic acid equiv./100 g, $400 \pm 0.00 \mathrm{mg}$ quercetin equiv./100 g and $263.73 \pm 0.00 \mathrm{mg}$ Cy-3-G equiv./100 g, respectively. Peak viscosity and gelatinization temperature of RRF were lower than that of rice flour, resulting in swelling power, water solubility index, and water absorption index of RRF were higher than rice flour. Flour formulas for rice noodles preparation were made by substituted rice flour with Riceberry rice flour from 10-50\% (by total flour weight). The amount of RRF decreased the peak viscosity, break down, and final viscosity but increased gelatinization temperature of composite flours. The optimum ratio of RRF was $20 \%$ supplemented into rice noodles showed overall acceptance including good cooking quality, texture, and consumer acceptance. The result of this study could be used as knowledge in food application as functional foods, especially in the development of rice noodles of Ubon Ratchathani province, Thailand to promote the economic potential of the local community.
\end{abstract}

\section{Introduction}

Riceberry rice, having dark purple- colored grains, was a crossed-bred strain from Khao Hom Nin Rice variety and Khao Hom Mali 105 developed by Rice Research Center, Kasetsart University, Thailand. It contains many bioactive compounds such as grammaoryzanol, anthocyanins, flavonoid, niacin, thiamin, vitamin $\mathrm{B} 2$, beta-carotene, $\mathrm{Zn}$, and total phenolic compounds. Besides, its purple pigment can be widely used as food colorants when processing bread, ice creams and liquor (Ryu et al., 1998). Moreover, Riceberry rice has a low glycemic index; cyanidin3glucoside (Cy-3-Glc) in black/purple rice has been reported to be one of the major antioxidant compounds (Ryu et al., 1998). Therefore, pigmented rice has become a popular alternative for health-conscious consumers.
Rice noodle is the one traditional staple food in NorthEast of Thailand especially in Ubon Ratchathani province and has called Ubon noodles. Rice noodle in Ubon Ratchathani province has believed as an original noodle in Vietnam and then spread to Thailand probably during the early Ayutthaya period (B.C.1350). This noodle is made mainly from two types of flours such as rice and tapioca flour, both are deficient in essential nutritional components such as dietary fiber, vitamins, and minerals then lost during the flour refining process. Presently, a high noodle marketing competition in Thailand is remarkably high. Thus, noodle products represented as healthy food with wonderful colors and suitable for enhancing health after supplement by adding nutritional substances. To develop a new product based on consumer demand, the food technologist has to concerns about the nutritional aspects and material 
properties used. The high ability of flour to absorb water and high setback property are required parameters for rice noodles products. Accordingly, physicochemical properties, functional properties, and fantastic color of RRF may have significant effects on the overall quality and acceptability of rice noodles. Noodles made from wheat flour substituted with RRF had lower water adsorption, cooking time, and higher cooking loss compared to noodles produced from wheat flour alone (Sirichokworrakit et al., 2015). Thus, some researcher has improved the physical properties of noodles produced from wheat flour and RRF by using hydrocolloids (Chokchaithanawiwat et al., 2019). Therefore, the objectives of this study are first to determine the physicochemical and functional properties of RRF, secondly to test a partial replacement of rice flour with RRF in Ubon noodles making, and thirdly to investigate the effects of RRF on the rice noodles texture and cooking quality.

\section{Materials and methods}

\subsection{Materials}

Riceberry rice with $13 \%$ moisture content was purchase from Bak-Ham organic rice group (Ubon Ratchathani province, Thailand). Rice flour (RF) and tapioca flour (TF) were obtained from the local market.

\subsection{Riceberry rice flour preparation}

Riceberry rice grains were dried at $55^{\circ} \mathrm{C}$ until the moisture content access lower than $13 \%$, then grinding grains into powder. Riceberry rice powder was passed through an 80 mesh sieve $(180 \mu \mathrm{m})$ and further vacuum packed in a laminated aluminum foil bag. Riceberry rice flour (RRF) was stored at $4^{\circ} \mathrm{C}$ before further analysis.

\subsection{Proximate analysis}

Moisture (method 934.01), crude protein (method 922.15 (39.1.16), crude fat (method 954.02) and crude fiber (method 978.10) content of RRF were determined according to AOAC approved standard methods (AOAC, 2000). Amylose content was examined by the colorimetry method described in Juliano (1971). RRF $100 \mathrm{mg}$ was mixed with $1 \mathrm{~mL}$ of $95 \%$ ethanol and $9 \mathrm{~mL}$ of $2 \mathrm{~N} \mathrm{NaOH}$, then adjusted to $100 \mathrm{~mL}$ with distilled water. The mixture solution was further added with $2 \mathrm{~mL}$ of $0.2 \%$ iodine solution. The color development of the solution was determined at the absorbance as $620 \mathrm{~nm}$ using spectrophotometer (LIBRA S11 UV-Vis spectrophometer, England). All data were calculated as a percentage on a wet basis.

\subsection{Determination of total phenolic contents (TPC)}

The total phenolic content of both free and bound phenolics extracts was evaluated by using modifications of the Folin-Ciocalteau method (Paiva et al., 2014) with slight modification. RRF ( $2 \mathrm{~g})$ was extracted two times with $80 \%$ methanol at a ratio of $1: 10(\mathrm{w} / \mathrm{v})$. The extraction mixture was shaken at $200 \mathrm{rpm}$ for $1 \mathrm{hr}$ at room temperature before centrifugation at $4500 \mathrm{rpm}$ for 5 mins. The supernatants were concentrated and dried by using a rotary evaporator at $35^{\circ} \mathrm{C}$. The dried methanol extract was dissolved in $20 \mathrm{~mL}$ of $50 \%$ methanol and used as crude extracts for total free phenolics determination. Gallic acid was used for calibration and results were expressed as $\mathrm{mg}$ of gallic acid equivalents (GAE) per $100 \mathrm{~g}$ of rice on a dry weight basis.

\subsection{Determination of total flavonoid content (TFC)}

The total flavonoids content was measured according to the method described by Paiva et al. (2014). The extract for quantification of total flavonoids was prepared by adding $40 \mathrm{~mL}$ of $70 \%$ acetone in water (v/v) to $2 \mathrm{~g}$ of RRF, then vortexed and placed in an ultrasonic water-bath for 20 mins. The slurry was centrifuged at $3000 \times g\left(4^{\circ} \mathrm{C}\right)$ for 10 mins. The supernatant $(0.5 \mathrm{~mL})$ was added with $2.25 \mathrm{~mL}$ of distilled water and $0.15 \mathrm{~mL}$ of $5 \%$ sodium nitrite solution in a test tube, then mixed and kept for 6 mins. Afterwards, $0.3 \mathrm{~mL}$ of a $10 \%$ aluminium trichloride hexahydrate solution was added, then vortexed and allowed to stand for $5 \mathrm{mins}$, followed by the addition of $1 \mathrm{~mL}$ of $1 \mathrm{M}$ sodium hydroxide. The mixture was vortexed again and absorbance was measured immediately at $510 \mathrm{~nm}$ (LIBRA S11 UV-Vis spectrophotometer, England). Results were expressed as $\mathrm{mg}$ of quercetin equivalents per $100 \mathrm{~g}$ of sample.

\subsection{Determination of total anthocyanins}

Total anthocyanin content in RRF was determined according to the spectrophotometric method described by Abdel-Aal and Hucl, (1999) with slight modification. Anthocyanins were extracted from $0.5 \mathrm{~g}$ of RRF using acidified methanol (methanol and $1.0 \mathrm{~N} \mathrm{HCl}, 85: 15$, v/v). Extracts were centrifuged at 27,200 $\times g$ for $15 \mathrm{mins}$ and repeated three more times, then the supernatants combined. The extracts were filtered through a $0.45 \mu \mathrm{m}$ filter and absorbance was recorded at $535 \mathrm{~nm}$. The total anthocyanin contents of the samples were calculated as $\mathrm{mg}$ of cyanidin-3-glucoside equivalent (Cy-3-G) per 100 $\mathrm{g}$ of sample.

\subsection{Determination color attributes}

The color RRF and rice noodles were determined by using spectrophotometer (Hunter lab, Color Flex 45/0, 
USA). The color parameters were $\mathrm{L}^{*}\left(\mathrm{~L}^{*}=0\right.$, black and $\mathrm{L}^{*}=100$, white $), \mathrm{a}^{*}\left(-\mathrm{a}^{*}=\right.$ greenness and $+\mathrm{a}^{*}=$ redness $)$ and $b^{*}\left(-b^{*}=\right.$ blueness and $+b^{*}=$ yellowness $)$ were recorded. The colorimeter was calibrated with a white calibrate tile before measuring.

\subsection{Pasting properties of flour}

A rapid visco analyser (RVA, NEWPORT, Model RVA-4, USA) was used for determining the pasting properties. The samples $(3 \mathrm{mg})$ were placed in a canister and added with $25 \mathrm{~mL}$ distilled water. Viscosity profiles were recorded under setting conditions as holding temperature at $50^{\circ} \mathrm{C}$, for $1 \mathrm{~min}$; then raised to $95^{\circ} \mathrm{C}$ at the rate of $1.5^{\circ} \mathrm{C} / \mathrm{min}$ and kept for 20 mins. The sample was then cooled down to $50^{\circ} \mathrm{C}$ at the rate of $1.5^{\circ} \mathrm{C} / \mathrm{min}$. Peak viscosity, trough viscosity, breakdown, final viscosity, setback, and pasting temperature were recorded.

\subsection{Thermal properties of flour}

Thermal properties were determined with a differential scanning calorimetry (DCS, METTLERTOLEDO, Switzerland) according to Bhattacharya et al. (1999). Each sample (3 g) were placed in an aluminum crucible, then distilled water was added to obtain a flourto-water ratio of $1: 3(\mathrm{w} / \mathrm{w})$. The crucible was sealed and allowed to equilibrate for $1 \mathrm{~h}$ before analysis. The samples were heated from $30^{\circ} \mathrm{C}$ to $110^{\circ} \mathrm{C}$ at the rate of $10^{\circ} \mathrm{C} / \mathrm{min}$, and an empty crucible was used as a reference. The DSC parameters including the onset $\left(T_{\mathrm{o}}\right)$, peak $\left(T_{\mathrm{p}}\right)$, conclusion temperature $\left(T_{\mathrm{c}}\right)$ and gelatinization enthalpy $(\Delta H)$ were recorded.

\subsection{Water absorption index (WAI), water solubility index (WSI) and swelling power of flour}

Water absorption index (WAI) and water solubility index (WSI) of flour composites were determined according to the method of Wandee et al. (2015) with slight modification. Flour samples $(0.5 \mathrm{~g})$ were suspended in $15 \mathrm{~mL}$ of distilled water in a centrifuge tube, and then vigorously mixed with a vortex mixer for $1 \mathrm{~min}$ before placing in a water bath shaker at $30^{\circ} \mathrm{C}$ for 25 mins. Then all samples were centrifuged at $3000 \mathrm{rpm}$ for $10 \mathrm{mins}$, the supernatants were carefully transferred to aluminum moisture can before dried at $105^{\circ} \mathrm{C}$ overnight. The sediments left were weighed and calculated as WAI, WSI and swelling power.$$
\text { WAI }(\mathrm{g} / \mathrm{g})=\frac{\text { weight of wet sediment }(\mathrm{g})}{\text { Dry weight of flour }(\mathrm{g})} \times 100
$$$$
\text { WSI(\%) }=\frac{\text { weight of dried supernatant }(\mathrm{g})}{\text { Dry weight of flour }(\mathrm{g})} \times 100
$$$$
\text { Swelling power }(\%)=\frac{\text { weight of wet sediment }(\mathrm{g})}{\text { Dry weight of flour }(\mathrm{g})} \times[100-\text { Weight of dried supernatant }(\mathrm{g})]
$$

\subsection{Rice noodles preparation}

The basic rice noodles formula consisted of $500 \mathrm{~g}$ of rice flour and $500 \mathrm{~g}$ of tapioca flour, $600 \mathrm{~mL}$ of distilled water. Six additional noodles samples were prepared by substituting rice flour with Riceberry rice flour (the mixing ratio of flour composites is showed in Table 1). The different flour formulas were processed into rice noodles using the mixer, the dough was passed through a small noodle machine to make noodle strands.

Table 1. Sample formulations

\begin{tabular}{|c|c|c|c|c|c|c|}
\hline Flour ingredients & $\underset{\pi}{\pi}$ & 쥼 & $\underset{\pi}{\widetilde{D}} \stackrel{0}{0}$ & 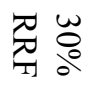 & ఇ & 쥼 \\
\hline Rice flour & 50 & 40 & 30 & 20 & 10 & 0 \\
\hline Riceberry rice flour & 0 & 10 & 20 & 30 & 40 & 50 \\
\hline Tapioca flour & 50 & 50 & 50 & 50 & 50 & 50 \\
\hline
\end{tabular}

\subsection{Cooking yield and cooling loss of noodles}

The cooking yield and cooking loss were determined according to the method of AACC (1995) with slight modification. Dried rice noodles $(1.0 \mathrm{~g})$ were cut into small pieces (3-5 cm in length) and boiled in $30 \mathrm{~mL}$ water until completely cooked (cooking time). The cooked noodles were then filtered through a stainless screen, cooled down with distilled water, drained for 1 min, and immediately weighed. The cooking yield was determined from the difference between noodle weights before and after cooking and expressed as the percentage of $\mathrm{g}$ cooked noodle/g dried noodle. Cooking loss was determined by evaporated the cooking water and rinse water in a hot-air oven at $105^{\circ} \mathrm{C}$ and was calculated as the percentage of solid loss during cooking.

\subsection{Noodle texture analysis}

Texture properties of noodles were measured using a texture analyzer (LLOYD model LRSK series, USA) according to the conditions of Han et al. (2011) with slight modification. The measurement condition was set as test speed $1 \mathrm{~mm} / \mathrm{s}$, and a trigger force of $5 \mathrm{~g}$ using a 5 $\mathrm{kg}$ load cell. Two texture parameters were recorded: tensile strength (maximum load; N) required to resist the extension of cooked noodle strand, and breaking length (deflection at yield; $\mathrm{mm}$ ) indicates extensibility of the noodle.

\subsection{Sensory evaluation of noodles}

All noodles samples were boiled using drinking water for the optimum time. The noodles quality was evaluated for appearance, color, flavor, taste, softness, and overall acceptability of the samples by 30 untrained panelists but they were made acquainted with the use of hedonic scale and the texture parameters to be used for sensory analysis. The samples were evaluated using a 
nine-point hedonic scale $(1=$ very undesirable; $2=$ undesirable; $3=$ moderately undesirable; $4=$ slightly undesirable; $5=$ neither undesirable nor desirable; $6=$ slightly desirable; $7=$ moderately desirable; $8=$ desirable; $9=$ very desirable).

\subsection{Statistic analysis}

The design of the experiment of chemical and physicochemical analysis was performed by completely randomized design (CRD) and for sensory evaluation was conducted by randomized complete block design (RCBD). The data in the tables are expressed as means \pm standard deviation. The results were subjected to statistical Duncan's analysis on SPSS 17.0 (SPSS Inc. US Chicago) to determine whether there was a significant difference $(\mathrm{P}<0.05)$ in each attribute.

\section{Results and discussion}

\subsection{Chemical composition of flours}

RRF showed a high content of protein $(9.50 \%)$, fat $(6.38 \%)$ and fiber $(1.78 \%)$ which higher than white rice flour. This result was in good agreement with Kraithong et al. (2018) who reported values of crude protein, crude fat and amylose content in Riceberry rice were 7.54, 3.60 and $23.33 \%$, respectively. Bioactive compounds including anthocyanins, flavonoids and total phenolics containing in RRF (Table 2) are $263.73 \mathrm{mg}$ Cy-3-G equiv/100 g, $400 \mathrm{mg}$ quercetin equiv./100 $\mathrm{g}$ and $495 \mathrm{mg}$ gallic acid equiv./100 g, respectively. These compounds had reported as very strong antioxidants and protecting the body against oxidative damage and reduce risk of diseases caused by prolonged exposure to smoking, pollution and free radical formation inside the body and also act as anti-carcinogenic and anti-allergic agents by reducing the histamine formation in the body ( $\mathrm{Gu}$ et al., 2004). The obvious redness color $\left(\mathrm{a}^{*}=6.43\right)$ presented in RRF is influenced by its phenolic compounds, including anthocyanins (blueness and purpleness), proanthocyanins (redness) and carotenoids (Anggraini et al., 2015).

\subsection{Functional and thermal properties of flours}

The functional properties of flours presented in Table 3. The swelling power (12.52-15.22\%), solubility index (29.78-36.33\%) and water absorption index (34.33 $-86.33 \%$ ) of RRF, RF, and TF were significantly different $(\mathrm{p}<0.05)$ for all samples. The highest water absorption index found in RRF indicated that a high number of hydrophilic groups contributed within starch molecules and providing softness, smoothness, and viscosity in food products (Aprianita et al., 2014). In this study, RRF has a higher water absorption index in the molecule more than RF due to it contains high protein content to encourages strong hydrogen bonding with water (Prasad et al., 2012). High peak viscosity is mainly promoted by high amylopectin content because of water holding capacity (Ye et al., 2016). Consequently, it is possible that RRF has a high WAI but shows a low peak viscosity (Table 4) because it contains low amylopectin content.

Thermal properties of flours that used to prepared rice noodles also presented in Table 3 . There is a

Table 2. Chemical composition, bioactive compounds and color of flours.

\begin{tabular}{lccc}
\hline \multicolumn{1}{c}{ Bioactive compound/color } & Riceberry rice flour & Rice flour & Tapioca flour \\
\hline Protein $(\% \mathrm{wb})$ & $9.50 \pm 0.13$ & $6.50 \pm 0.40$ & $0.13 \pm 0.04$ \\
Fat $(\% \mathrm{wb})$ & $6.38 \pm 0.06$ & $2.09 \pm 0.21$ & $0.23 \pm 0.00$ \\
Amylose $(\% \mathrm{wb})$ & $23.33 \pm 0.00$ & $20.93 \pm 0.01$ & $16.50 \pm 0.00$ \\
Anthocyanins (mg Cy-3-G equiv./100 g) & $263.73 \pm 0.00$ & - & - \\
Total Phenolics (mg gallic acid equiv./100 g) & $495.00 \pm 0.00$ & - & - \\
Flavonoids (mg quercetin equiv./100 g) & $400.00 \pm 0.00$ & - & - \\
$\mathrm{L}^{*}$ & $55.91 \pm 0.04$ & - & - \\
$\mathrm{a}^{*}$ & $6.43 \pm 0.07$ & - & - \\
$\mathrm{b}^{*}$ & $3.38 \pm 0.09$ & - & - \\
\hline
\end{tabular}

Values are expressed as mean \pm standard deviation of three replications of each sample.

Table 3. Functional and thermal properties of flours.

\begin{tabular}{lccc}
\hline \multicolumn{1}{c}{ Functional Properties } & Riceberry rice flour & Rice flour & Tapioca flour \\
\hline Swelling power $(\%)$ & $13.65 \pm 0.38^{\mathrm{b}}$ & $12.52 \pm 0.04^{\mathrm{c}}$ & $15.22 \pm 0.12^{\mathrm{a}}$ \\
WSI $(\%)$ & $31.01 \pm 2.31^{\mathrm{b}}$ & $29.78 \pm 1.16^{\mathrm{c}}$ & $36.33 \pm 2.31^{\mathrm{a}}$ \\
WAI $(\%)$ & $86.33 \pm 2.30^{\mathrm{a}}$ & $51.00 \pm 0.00^{\mathrm{b}}$ & $34.33 \pm 2.08^{\mathrm{c}}$ \\
Onset temp. $\left({ }^{\circ} \mathrm{C}\right)$ & $62.09 \pm 1.04^{\mathrm{b}}$ & $70.51 \pm 0.07^{\mathrm{a}}$ & $60.50 \pm 0.14^{\mathrm{c}}$ \\
Peak temp. $\left({ }^{\circ} \mathrm{C}\right)$ & $70.76 \pm 0.34^{\mathrm{b}}$ & $74.00 \pm 0.06^{\mathrm{a}}$ & $65.76 \pm 0.29^{\mathrm{c}}$ \\
Gelatinization enthalpy $(\mathrm{J} / \mathrm{g})$ & $9.05 \pm 1.14^{\mathrm{c}}$ & $11.16 \pm 0.25^{\mathrm{b}}$ & $15.55 \pm 0.68^{\mathrm{a}}$ \\
Conclusion temp. $\left({ }^{\circ} \mathrm{C}\right)$ & $76.23 \pm 0.04^{\mathrm{b}}$ & $78.83 \pm 0.04^{\mathrm{a}}$ & $72.57 \pm 0.37^{\mathrm{c}}$ \\
\hline
\end{tabular}

Values are expressed as mean \pm standard deviation of three replications of each sample. Values with different letter superscript within row are significantly different $(\mathrm{p}<0.05)$. 
Table 4. Pasting properties of flours.

\begin{tabular}{lccc}
\hline \multicolumn{1}{c}{ Pasting Properties } & Riceberry rice flour & Rice flour & Tapioca flour \\
\hline Peak viscosity $(\mathrm{cP})$ & $1949.00 \pm 42.72^{\mathrm{c}}$ & $2494.33 \pm 79.35^{\mathrm{b}}$ & $4669.00 \pm 9.54^{\mathrm{a}}$ \\
Through $(\mathrm{cP})$ & $1643.33 \pm 74.93^{\mathrm{b}}$ & $1774.67 \pm 62.61^{\mathrm{a}}$ & $1565.33 \pm 10.41^{\mathrm{c}}$ \\
Breakdown $(\mathrm{cP})$ & $290.33 \pm 27.61^{\mathrm{c}}$ & $807.67 \pm 17.69^{\mathrm{b}}$ & $3101.67 \pm 1.53^{\mathrm{a}}$ \\
Final Viscosity $(\mathrm{cP})$ & $2827.67 \pm 59.72^{\mathrm{c}}$ & $3334.67 \pm 28.36^{\mathrm{a}}$ & $2942.67 \pm 1.53^{\mathrm{b}}$ \\
Setback $(\mathrm{cP})$ & $876.67 \pm 17.00^{\mathrm{a}}$ & $840.34 \pm 5.99^{\mathrm{b}}$ & $-1726.00 \pm 8.01^{\mathrm{c}}$ \\
Pasting Temp $\left({ }^{\circ} \mathrm{C}\right)$ & $71.21 \pm 0.15^{\mathrm{b}}$ & $74.60 \pm 3.36^{\mathrm{a}}$ & $65.70 \pm 0.20^{\mathrm{c}}$ \\
\hline
\end{tabular}

Values are expressed as mean \pm standard deviation of three replications of each sample. Values with different letter superscript within row are significantly different $(\mathrm{p}<0.05)$.

Table 5. Pasting and thermal properties of composite flours.

\begin{tabular}{lcccccc}
\hline Composite Flour & $\begin{array}{c}\text { Peak viscosity } \\
(\mathrm{cP})\end{array}$ & $\begin{array}{c}\text { Breakdown } \\
(\mathrm{cP})\end{array}$ & $\begin{array}{c}\text { Final Viscosity } \\
(\mathrm{cP})\end{array}$ & $\begin{array}{c}\text { Setback } \\
(\mathrm{cP})\end{array}$ & $\begin{array}{c}\text { Onset temp } \\
T o\left({ }^{\circ} \mathrm{C}\right)\end{array}$ & $\begin{array}{c}\text { Peak temp } \\
T p\left({ }^{\circ} \mathrm{C}\right)\end{array}$ \\
\hline $0 \% \mathrm{RRF}$ & $3393.00 \pm 82.02^{\mathrm{a}}$ & $973.67 \pm 20.82^{\mathrm{a}}$ & $3047.00 \pm 49.43^{\mathrm{a}}$ & $-356.00 \pm 32.59^{\mathrm{c}}$ & $55.39 \pm 0.18^{\mathrm{d}}$ & $66.52 \pm 1.05^{\mathrm{ab}}$ \\
$10 \% \mathrm{RRF}$ & $2384.33 \pm 43.98^{\mathrm{b}}$ & $781.67 \pm 26.16^{\mathrm{b}}$ & $2609.33 \pm 15.18^{\mathrm{b}}$ & $225.00 \pm 28.80^{\mathrm{c}}$ & $56.81 \pm 0.04^{\mathrm{cd}}$ & $65.78 \pm 0.31^{\mathrm{b}}$ \\
$20 \% \mathrm{RRF}$ & $2194.33 \pm 95.66 \mathrm{e}^{\mathrm{c}}$ & $658.00 \pm 20.30^{\mathrm{c}}$ & $2557.67 \pm 19.55^{\mathrm{b}}$ & $363.34 \pm 76.11^{\mathrm{c}}$ & $57.70 \pm 0.30^{\mathrm{c}}$ & $66.69 \pm 0.45^{\mathrm{ab}}$ \\
$30 \% \mathrm{RRF}$ & $2091.33 \pm 63.53^{\mathrm{c}}$ & $509.33 \pm 8.50^{\mathrm{d}}$ & $2222.00 \pm 53.45^{\mathrm{c}}$ & $130.67 \pm 10.08^{\mathrm{b}}$ & $58.51 \pm 0.28^{\mathrm{c}}$ & $67.59 \pm 0.04^{\mathrm{a}}$ \\
$40 \% \mathrm{RRF}$ & $2050.33 \pm 51.16^{\mathrm{c}}$ & $446.00 \pm 14.80^{\mathrm{e}}$ & $2162.33 \pm 47.48^{\mathrm{c}}$ & $112.00 \pm 3.68^{\mathrm{b}}$ & $60.76 \pm 0.16^{\mathrm{b}}$ & $67.29 \pm 0.06^{\mathrm{a}}$ \\
$50 \% \mathrm{RRF}$ & $1837.67 \pm 33.62^{\mathrm{d}}$ & $430.67 \pm 19.55^{\mathrm{f}}$ & $2046.67 \pm 52.17^{\mathrm{d}}$ & $209.00 \pm 18.55^{\mathrm{a}}$ & $61.78 \pm 1.85^{\mathrm{a}}$ & $67.82 \pm 0.28^{\mathrm{a}}$ \\
\hline
\end{tabular}

Values are expressed as mean \pm standard deviation of three replications of each sample. Values with different letter superscript within column are significantly different $(\mathrm{p}<0.05)$.

significant difference in onset, peak, conclusion, and gelatinization enthalpy for all samples $(\mathrm{p}<0.05)$. The various properties of flours are relating to the presence of crystallinity and chemical compositions such as amylose, lipid, and protein content in their molecules (Prasad et al., 2012; Zeng et al., 2015). The energy requirement (DH) of RRF was higher compared with rice flour, indicating that it needs higher energy for disrupting the large crystalline regions of high amylopectin content. Moreover, the formation of amylose-lipid and/or amylose-protein complex in colored-rice flour with a rigid structure that may affect the gelatinization temperature of this rice (Ugarčić-Hardi et al., 2007). Therefore, composite flours containing a high proportion of RRF causes a higher in thermal properties especially $T_{0}$ and $T_{\mathrm{p}}$ (Table 5).

\subsection{Pasting properties of flours}

The pasting profile (RVA) of flours showed in Table 4. The lowest peak viscosity $(1949 \mathrm{cP})$ of RRF $(\mathrm{p}<0.05)$ indicates a low ability of starch granule to bind with water via hydrogen bonding. Moreover, a low peak viscosity (1949 cP) of RRF caused by lower breakdown because more heat and shear stress assistance during cooking (Hue et al., 2015). RRF has the highest setback $(876.67 \mathrm{cP})(\mathrm{p}<0.05)$ which probably may be used in sticky rice noodles, fried snacks, etc. to provide foods structure (Ahmed et al., 2015). Pasting properties of composite flour (Table 5) are vary depending on RF composition such as amylose content that influenced on swelling property because of its tightly packed form (Wang et al., 2016). Besides, a re-association of amylose consequent to cooling caused a formation of three- dimensional structure induced increasing of setback value (Jamal et al., 2016). Consequently, composite flours containing RRF has more amylose content then provide a low peak, trough, and breakdown viscosity but high setback, final viscosity and pasting temperature.

\subsection{Cooking quality of noodles}

Cooking qualities of noodles supplemented with RRF presented in Table 6 . The good qualities of noodle support to have short cooking time, low cooking loss, and high cooking yield. The results indicated that noodles manufactured from rice flour $(0 \% \mathrm{RRF})$ have a longer cooking time and higher cooking loss than noodles supplemented with RRF, while noodles containing RRF had a cooking yield higher than noodles produced from rice flour probably due to the high WSI/ WAI of RRF affected on water absorption in noodles structure. It has contributed by a high number of hydrophilic groups contribute within starch molecules of RRF (Aprianita et al., 2014). Increasing the proportion of RRF in noodles contributed to an increasing in

Table 6. Cooking quality of rice noodles substituted with RRF.

\begin{tabular}{lccc}
\hline Sample & $\begin{array}{c}\text { Cooking time } \\
(\mathrm{min})\end{array}$ & $\begin{array}{c}\text { Cooking yield } \\
(\%)\end{array}$ & $\begin{array}{c}\text { Cooking loss } \\
(\%)\end{array}$ \\
\hline $0 \%$ RRF & 5 & $54.88 \pm 1.70^{\mathrm{c}}$ & $1.79 \pm 0.03^{\mathrm{a}}$ \\
$10 \%$ RRF & 5 & $62.64 \pm 1.42^{\mathrm{b}}$ & $1.77 \pm 0.02^{\mathrm{a}}$ \\
$20 \% \mathrm{RRF}$ & 4 & $63.23 \pm 0.05^{\mathrm{b}}$ & $1.67 \pm 0.04^{\mathrm{b}}$ \\
$30 \% \mathrm{RRF}$ & 3 & $67.45 \pm 0.98^{\mathrm{a}}$ & $1.55 \pm 0.10^{\mathrm{c}}$ \\
$40 \% \mathrm{RRF}$ & 2 & $67.96 \pm 1.51^{\mathrm{a}}$ & $1.43 \pm 0.01^{\mathrm{d}}$ \\
$50 \%$ RRF & 1 & $68.23 \pm 0.64^{\mathrm{a}}$ & $1.26 \pm 0.03^{\mathrm{e}}$ \\
\hline
\end{tabular}

Values are expressed as mean \pm standard deviation of three replications of each sample. Values with different letter superscript within column are significantly different $(p<0.05)$. 
cooking yield. This result implies that a high amount of water retention in the noodles structure may influence by a starch - lipid/protein complexes. Thereby, increasing the amount of RRF influenced the functional properties and cooking quality of gluten-free noodles.

\subsection{Texture and color of noodles}

The consumer acceptance of cooked noodles is determined based on textural and mouthfeel evaluation. The two factors such as maximum load and deflection at yield used to demonstrate the eating quality of cooked rice noodles produced from rice flour supplementing with RRF (Table 7). (Bhattacharya et al., 1999). Both the maximum load and deflection at yield were significantly different from the increase in RRF content. The decreasing of maximum load and deflection at yield by the addition of RRF higher than $10 \mathrm{~g} / 100 \mathrm{~g}$ total flour are relatively considerable. The results revealed that rice noodles supplemented with RRF had lower hardness and elasticity than noodles from rice flour. It probably since the RRF had a higher content of protein, lipid, and fiber than rice flour. Thus, amylose-lipid and amylose-protein formation in pigmented rice flour retard retrogradation in noodles after cooling. Therefore, the addition of RRF has higher water retention in noodles caused weak structures formed in the noodle. Color is one of the most important parameters in evaluating consumer perception. Color features of cooked rice noodles supplemented with RRF presented in Table 7 and Figure 1. The results showed that the color of supplemented rice noodles with RRF has higher $a^{*}$ value than noodles without RRF. The appearance of the more reddish color of rice noodles containing RRF effects from the natural color (anthocyanin) containing in RRF.

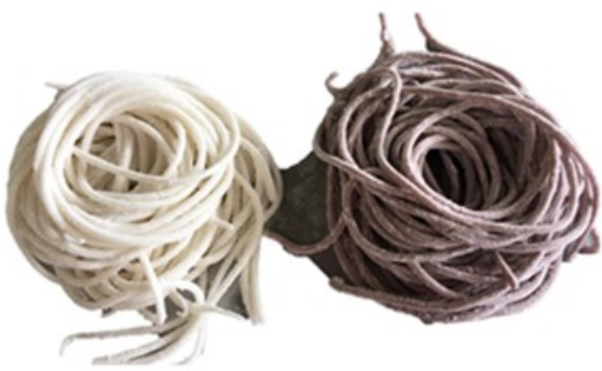

(A)

(B)

Figure 1. Ubon rice noodles without RRF (A) and supplemented with $20 \%$ RRF (B).

\subsection{Sensory evaluation of noodles}

The sensory characteristic such as appearance, color, taste, softness, and overall acceptability of cooked rice noodles supplemented with RRF presented in Table 8 . Noodles containing RRF had significantly decreased in sensory scores as the RRF content increased while noodles supplemented with RRF higher than $30 \mathrm{~g} / 100 \mathrm{~g}$ showed not significantly of the softness. Like the changes in texture properties of cooked noodles, the decrease in sensory characteristics was attributed mainly to the weakened structure of starch due to excess water uptake during cooking. Generally, the water absorption level higher than $38 \%$ influences the amount of work required during strand forming and color changed of the noodles, thereby too much water causes dough stickiness

Table 7. Physical properties of rice noodles substituted with RRF.

\begin{tabular}{lccccc}
\hline Sample & $\begin{array}{c}\text { Maximum Load } \\
(\mathrm{N})\end{array}$ & $\begin{array}{c}\text { Deflection at yield } \\
(\mathrm{mm})\end{array}$ & $\mathrm{L}^{*}$ & $\mathrm{a}^{*}$ & $\mathrm{~b}^{*}$ \\
\hline $0 \% \mathrm{RRF}$ & $0.052 \pm 0.004^{\mathrm{a}}$ & $48.76 \pm 6.24^{\mathrm{a}}$ & $68.37 \pm 0.22^{\mathrm{a}}$ & $-2.72 \pm 0.05^{\mathrm{d}}$ & $5.09 \pm 0.06^{\mathrm{a}}$ \\
$10 \% \mathrm{RRF}$ & $0.041 \pm 0.005^{\mathrm{b}}$ & $43.19 \pm 4.86^{\mathrm{b}}$ & $40.15 \pm 0.06^{\mathrm{b}}$ & $6.08 \pm 0.12^{\mathrm{c}}$ & $5.06 \pm 0.17^{\mathrm{b}}$ \\
$20 \% \mathrm{RRF}$ & $0.036 \pm 0.002^{\mathrm{c}}$ & $35.97 \pm 2.75^{\mathrm{c}}$ & $33.58 \pm 0.12^{\mathrm{c}}$ & $7.77 \pm 0.13^{\mathrm{b}}$ & $3.58 \pm 0.17^{\mathrm{c}}$ \\
$30 \% \mathrm{RRF}$ & $0.032 \pm 0.004^{\mathrm{d}}$ & $33.37 \pm 5.60^{\mathrm{d}}$ & $32.14 \pm 0.52^{\mathrm{d}}$ & $7.78 \pm 0.23^{\mathrm{b}}$ & $2.76 \pm 0.12^{\mathrm{d}}$ \\
$40 \% \mathrm{RRF}$ & $0.029 \pm 0.002^{\mathrm{e}}$ & $28.17 \pm 3.47^{\mathrm{e}}$ & $24.57 \pm 0.04^{\mathrm{e}}$ & $7.88 \pm 0.28^{\mathrm{b}}$ & $1.46 \pm 0.16^{\mathrm{e}}$ \\
$50 \% R R F$ & nd & nd & $21.08 \pm 0.14^{\mathrm{f}}$ & $8.92 \pm 0.18^{\mathrm{a}}$ & $1.53 \pm 0.22^{\mathrm{f}}$ \\
\hline
\end{tabular}

Values are expressed as mean \pm standard deviation of three replications of each sample. Values with different letter superscript within column are significantly different $(\mathrm{p}<0.05)$. nd, not detected.

Table 8. Sensory evaluation of rice noodles substituted with RRF

\begin{tabular}{lccccc}
\hline Sample & Appearance & Color & Taste & Softness & Overall \\
\hline $0 \%$ RRF & $7.08 \pm 1.31^{\mathrm{a}}$ & $7.10 \pm 1.28^{\mathrm{a}}$ & $6.40 \pm 1.45^{\mathrm{a}}$ & $6.98 \pm 1.48^{\mathrm{a}}$ & $7.25 \pm 1.28^{\mathrm{a}}$ \\
$10 \% \mathrm{RRF}$ & $6.88 \pm 1.31^{\mathrm{b}}$ & $6.75 \pm 1.28^{\mathrm{ab}}$ & $6.70 \pm 1.38^{\mathrm{a}}$ & $6.98 \pm 1.37^{\mathrm{a}}$ & $7.23 \pm 1.10^{\mathrm{a}}$ \\
$20 \% \mathrm{RRF}$ & $7.08 \pm 1.25^{\mathrm{a}}$ & $6.55 \pm 1.32^{\mathrm{ab}}$ & $6.23 \pm 1.39^{\mathrm{a}}$ & $6.48 \pm 1.71^{\mathrm{a}}$ & $6.95 \pm 1.34^{\mathrm{a}}$ \\
$30 \% \mathrm{RRF}$ & $6.00 \pm 1.24^{\mathrm{c}}$ & $6.23 \pm 1.19^{\mathrm{b}}$ & $4.83 \pm 1.87^{\mathrm{b}}$ & $4.23 \pm 2.01^{\mathrm{b}}$ & $5.13 \pm 1.92^{\mathrm{b}}$ \\
$40 \% \mathrm{RRF}$ & $4.73 \pm 1.87^{\mathrm{d}}$ & $5.53 \pm 1.65^{\mathrm{c}}$ & $3.93 \pm 1.91^{\mathrm{c}}$ & $3.50 \pm 2.12^{\mathrm{b}}$ & $4.28 \pm 1.91^{\mathrm{c}}$ \\
$50 \% R R F$ & $5.45 \pm 1.85^{\mathrm{c}}$ & $5.48 \pm 2.25^{\mathrm{c}}$ & $4.43 \pm 1.97^{\mathrm{bc}}$ & $3.93 \pm 2.01^{\mathrm{b}}$ & $4.68 \pm 1.87^{\mathrm{bc}}$ \\
\hline
\end{tabular}

Values are expressed as mean \pm standard deviation of three replications of each sample. Values with different letter superscript within column are significantly different $(\mathrm{p}<0.05)$. 
creating handling problems during noodle preparation. (Hatcher et al., 1999). However, insufficient water can produce the formation of non-cohesive in the dough and leading to lower noodle sheets expansion. Several researchers reported that the textural characteristics of cooked noodles observed to be negatively associated with increased water absorption in noodles (Edwards et al., 1996; Hatcher et al., 1999; Park and Baik, 2002).

\section{Conclusion}

Riceberry rice consists of several bioactive compounds such as anthocyanin, flavonoids, and total phenolic contents and has solubility and water absorption index higher than normal rice. RRF had lower gelatinization temperature and some values of pasting properties such as peak and breakdown but higher values of a setback compared to normal rice. Substitution of Riceberry rice flour to rice flour showed substantially improved the cooking quality of rice noodles, increased cooking yield, and decreased cooking loss comparable to the control $(0 \%$ RRF). However, for textural properties, the noodles made from RRF had weaker structure than noodles made from rice flour. Therefore, considering cooking properties, textural properties, and sensory evaluation we found that $20 \%$ of RRF effectively used as a replacement of rice flour for colored-noodles making with health-promoting and nutritive values.

\section{Conflict of interest}

The authors confirm that there are no known conflicts of interest associated with this publication and there has been no significant financial support for this work that could have influenced its outcome.

\section{Acknowledgments}

This work was supported by Ubon Ratchathani University and funded by the National Research Council of Thailand (NRCT).

\section{References}

AACC. (1995). Approved methods of AACC. 9th ed., St. Paul, Minnesota: American Association of Cereal Chemists.

Abdel-Aal, E.-S.M. and Hucl, P. (1999). A Rapid Method for Quantifying Total Anthocyanins in Blue Aleurone and Purple Pericarp Wheats. Cereal Chemistry, 76(3), 350-354. https://doi.org/10.1094/ CCHEM.1999.76.3.350

Ahmed, J., Al-Jassar, S. and Thomas, L. (2015). A Comparison in Rheological, Thermal, and Structural Properties between Indian Basmati and Egyptian
Giza Rice Flour Dispersions as Influenced by Particle Size. Food Hydrocolloids, 48, 72-83. https://doi.org/10.1016/j.foodhyd.2015.02.012

Anggraini, T., Novelina, U.L. and Amelia, R. (2015). Antioxidant Activities of Some Red, Black and White. Pakistan Journal of Nutrition, 14(2), 112117. https://doi.org/10.3923/pjn.2015.112.117

AOAC. (2000). Official Methods of Analysis of the Association of Official Analytical Chemist. 17th ed., Washington, DC., USA: Horwitz William Publication.

Aprianita, A., Vasiljevic, T., Bannikova, A. and Kasapis, S. (2014). Physicochemical Properties of Flours and Starches Derived from Traditional Indonesian Tubers and Roots. Journal of Food Science and Technology, 51(12), 3669-3679. https:// doi.org/10.1007/s13197-012-0915-5

Bhattacharya, M., Zee, S.Y. and Corke, H. (1999). Physicochemical Properties Related to Quality of Rice Noodles. Cereal Chemistry, 76(6), 861-867. https://doi.org/10.1094/CCHEM.1999.76.6.861

Chokchaithanawiwat, P., Rungsardthong, V., Thumthanaruk, B., Puttanlek, C., Uttapap, D., Boonraksa, S. and Wonngsa, J. (2019). Product Development of Dried Noodle from wheat Flour and Riceberry Rice Flour by Extrusion. IOP Conference Series: Earth and Environmental Science, 346, 012043. https://doi.org/10.1088/1755$1315 / 346 / 1 / 012043$

Edwards, N.M., Scanlon, M.G., Kruger, J.E. and Dexter, J.E. (1996). Oriental Noodle Dough Rheology: Relationship to Water Absorption, Formulation, and Work Input During Dough Sheeting. Cereal Chemistry, 73(6), 708-711.

Gu, L., Kelm, M.A., Hammerstone, J.F., Beecher, G., Holden, J., Haytowitz, D., Gebhardt, S. and Prior, R.L. (2004). Concentrations of Proanthocyanidins in Common Foods and Estimations of Normal Consumption. The Journal of Nutrition, 134(3), 613617. https://doi.org/10.1093/jn/134.3.613

Han, H.M., Cho, J.H. and Koh, B.K. (2011). Processing Properties of Korean Rice Varieties in Relation to Rice Noodle Quality. Food Science and Biotechnology, 20(5), 1277. https://doi.org/10.1007/ s10068-011-0176-5

Hatcher, D.W., Kruger, J.E. and Anderson, M.J. (1999). Influence of Water Absorption on the Processing and Quality of Oriental Noodles. Cereal Chemistry, 76 (4), 566-572. https://doi.org/10.1094/ CCHEM.1999.76.4.566

Jamal, S., Qazi, I.M. and Ahmed, I. (2016). Comparative Studies on Flour Proximate Compositions and 
Functional Properties of Selected Pakistani Rice Varieties. Proceedings of the Pakistan Academy of Sciences, 53(1), 47-56.

Juliano, B.O. (1971). A Simplified Assay for Milled Rice Amylose. Cereal Science Today, 16, 334-336.

Kraithong, S., Lee, S. and Rawdkuen, S. (2018). Physicochemical and Functional Properties of Thai Organic Rice Flour. Journal of Cereal Science, 79, 259-266. https://doi.org/10.1016/j.jcs.2017.10.015

Paiva, F.F., Vanier, N.L., Berrios, J.D.J., Pan, J., Villanova, F.D.A., Takeoka, G. and Elias, M.C. (2014). Physicochemical and Nutritional Properties of Pigmented Rice Subjected to Different Degrees of Milling. Journal of Food Composition and Analysis, 35(1), 10-17. https://doi.org/10.1016/ j.jfca.2014.05.003

Park, C.S. and Baik, B.-K. (2002). Flour Characteristics Related to Optimum Water Absorption of Noodle Dough for Making White Salted Noodles. Cereal Chemistry, 79(6), 867-873. https://doi.org/10.1094/ CCHEM.2002.79.6.867

Prasad, K., Singh, Y. and Anil, A. (2012). Effects of Grinding Methods on the Characteristics of Pusa 1121 Rice Flour. Journal of Tropical Agriculture and Food Science, 40(2), 193-201.

Ryu, S.N., Park, S.Z. and Ho, C.T. (1998). High Performance Liquid Chromatographic Determination of Anthocyanin Pigments in Some Varieties of Black Rice. Journal of Food and Drug Analysis, 6(4), 729736. https://doi.org/10.38212/2224-6614.2893

Sirichokworrakit, S., Phetkhut, J. and Khommoon, A. (2015). Effect of partial substitution of wheat flour with riceberry flour on quality of noodles. Procedia - Social and Behavioral Sciences, 197, 1006-1012. https://doi.org/10.1016/j.sbspro.2015.07.294

Ugarčić-Hardi, Z., Jukić, M., KoMLeNić, D.K., Sabo, M. and Hardi, J. (2007). Quality Parameters of Noodles Made with Various Supplements. Czech Journal of Food Sciences, 25(3), 151-157. https:// doi.org/10.17221/742-CJFS

Wandee, Y., Uttapap, D., Puncha-arnon, S., Puttanlek, C., Rungsardthong, V. and Wetprasit, N. (2015). Quality Assessment of Noodles Made from Blends of Rice Flour and Canna Starch. Food Chemistry, 179, 85-93. https://doi.org/10.1016/ j.foodchem.2015.01.119

Wang, L., Guo, J., Wang, R., Shen, C., Li, Y., Luo, X., Li, Y. and Chen, Z. (2016). Studies on Quality of Potato Flour Blends with Rice Flour for Making Extruded Noodles. Cereal Chemistry, 93(6), 593598. https://doi.org/10.1094/CCHEM-05-16-0147-R

Zeng, F., Ma, F., Kong, F., Gao, Q. and Yu, S. (2015).
Physicochemical Properties and Digestibility of Hydrothermally Treated Waxy Rice Starch. Food Chemistry, 172, 92-98. https://doi.org/10.1016/ j.foodchem.2014.09.020 